\title{
Women Empowerment Through Self Help Groups - A Study In Nalgonda District, Telangana.
}

\author{
P. KALPANA \\ Department Of Home Science Sri VenkateshwaraUniversity, Tirupati-517 502 (A.P.) Indiamay -2016
}

\begin{abstract}
Women empowerment is the ability to direct and control one's own life, but it is clear that suchan individual empowerment of women is attained in relationship to the larger society. It is a process in which women gain control over their lives by knowing and claiming their rights at allevels of society. The study is dealt with the Women Empowerment through self help groups. SHG is an organization with fundamental principles like democratic approach and common decision-making, transparency, self-helping, repayment of loans and group development. The credibility of the group is dependent on these principles. Not only economical progress but also an 'entire development' is the aim and mutual trust among the members is the credo of SHG.
\end{abstract}

Key words: Women Empowerment, SHG's, Nalgonda.

\section{INTRODUCTION}

Generally a rural woman is considered as inferior, illiterate, and ignorant and tool in the hand of man. From the age of 10 to 12 years, she is an earning member of the parents and after marriage she becomes the sole property of her husband and his family. A woman of rural area is treated as wife, a mother of her children and a sister-in- law of her husband's family. Through she supplements the income of her husband's family, she has no freedom to spend even a rupee without her husband's consent. The fundamental aim of promoting SHGs is poverty alleviation and to achieve empowerment of women. The recent trends show significant changes in the promotional strategies for the SHGs. Financial needs like banking, saving, insurance etc, getting subsidies, building organizations to gain political power also, are the purposes behind some of the SHGs.

\section{Objectives:}

The objectives of the present study are proposed the following objectives.

- To know the demographical profile of the members of Self-Help Groups.

- To assess the impact SHG participation and the extent of improvement among women beneficiaries after joining in the SHG Programme: On the lines of socio-economic status, educational status of respondents and their family members and on entrepreneurship development and empowerment of women, their health \&amp; nutritional status.

- To identify the successful women among the selected beneficiaries of Self Help Group by case studies.

\section{METHODOLOGY}

It contains details of the study area, sampling procedure, development of the interview schedule, data collection and statistical tools used for interpretation of the data.The main aim of the study was to examine the impact of participation of rural women in self help groups, on the socio economic aspects, family life style and on the nutritional status of women. The sample (respondents) is selected in Nalgonda Mandal were enlisted from 8 villages. 25 members from each village, Thus a total of 200 women were purposively selected for the study. The villages and the Mandal are described to be similar to other Mandal's of Nalgonda District in their sociodemography and development profiles.

\section{TOOLS FOR COLLECTION OF DATA}

It was intended to collect the data through interview technique and through case study method. In view of the methods of data collection following tools were used in the present investigation. Interview schedule was formulated to elicit information pertaining to the following areas.

1. General information

2. Economic empowerment of women

3. Social empowerment of women 
4. Rapid appraisal of health and nutritional status

The items included under the general information section are occupation, family type and size, income, educational status and details pertaining to the SHG membership and activities As a member. The items included under the economic empowerment are the increased access to income and control of resources, and utilization sectors of income, leadership skills etc. The items under the social empowerment include aspects pertaining to social status and decision making. The nutritional and health status assessment included a rapid appraisal survey method. The items included are about the access to food before and after becoming a member of self help groups, clinical survey to indentify to nutritional deficiency status anthropometric assessment for children and adults. Case study schedules were prepared and administered to a successful women through SHGs.

\section{INTERPRETATION OF DATA}

The before, after SHG technique is used particularly for assessment of improvements in economic status, social status, for the assessment of nutritional status. The data was pooled and computed using symbols, simple statistical techniques like percentages, bar graphs, and pie charts for different dependent variables of the study and the results was suitably interpreted with literature evidence. Case studies with successful stories focus height on how they became successful and what made them to be successful. Self Help Groups are the viable alternative to achieve the objectives of rural development programmes. Economic progress in any country could be achieved through social development. Empowering women contributes to social development. Women empowerment cannot be ignored while devising various policies for rural and socio-economic development. SHGs enhance the quality of status of women as participants decision makers and cultural spheres of life. Self Help Groups encourage women to take active part in the socio-economic progress of our nation. The SHGs have in calculated a great confidence in the mind of rural women to succeed in their day to day life. The success of the economic activities taken up by the self-employed persons largely depends on their social influence, their role in the decision making process, broader financial base through enhanced thrift and credit activities. Self Help Group a mini voluntary agency for self-help at the micro level has been a focus on the weaker sections particularly women for their social defense. SHGs has got potential in creating awareness on day to day affairs promoting savings habit, developing self and has got potential in creating awareness self and community assets, increasing income level, socio-economic characteristics of the sample population.

\section{The major findings of the study are:}

$>$ Most of the respondents (36\%) were in the age group of 30-40 years.

$>$ Majority of the respondents $(86.5 \%)$ were married i.e. 173 members and lowest number of unmarried respondents were only $1 \%$ i.e. 2 members.

$>$ The highest $(91 \%)$ of family size is between 1-4 members of the respondents. Majority of the families $(96 \%)$ were nuclear.

$>$ Majority of the houses $(98 \%)$ werepucca houses.

Most of the respondents $(76 \%)$ were illiterates.

$>$ Most of the respondents children were acquiring high school and higher education.

$>$ The major occupation of husbands of respondents was agriculture.

$>$ The $20 \%$ of the respondents were involved in income generating activities, remaining $80 \%$ were working along with the husband.

$>$ The major reason $(36 \%)$ to select the activity was to supplement the family income.

$>$ All of the respondents (100\%) were saving Rs. 100/- per month in the Self Help Groups.

$>$ Most of the respondents income between is Rs. 3000-3500/- i.e. $48 \%$ before the joining of SHG. Where as the increased income is between Rs. 500-1000/- i.e. 21.5\% after the joining of SHG.

$>$ Most of the respondents (34.5\%) utilized their income for providing the nutritional food for the family.

$>$ Majority (68\%) of respondents reported that decision making was by both wife and husband.

$>$ Most $(47.5 \%)$ of the respondents improved their family living conditions after joining as the Self-Help Group member.

$>$ The $100 \%$ women respondents had the financial self reliance. Most of the respondents (61\%) improved their financial status.

$>$ Majority of the respondents started their income generating activity at rural area after joining the SHG.

$>$ All $100 \%$ of the respondents participated in income generating activity and had the exposure through the programme.

$>$ Majority (91\%) of the respondents have equal status, participation and power of decision making of women in household. 
In the age group of 2-6 years, majority $(53.8 \%)$ girls were in severe condition of malnutrition and majority is $(44.4 \%)$ of boys were in normal condition. It is known that boys were in high percentage in normal levels of nutritional status when compared to girls. Which means a small portion of the girls were suffering from malnutrition.

$>$ In the age group of 7-12 years, majority of the boys $(50 \%)$ and girls were $(44.5 \%)$ in normal condition.

$>$ In the age group of 13-18 years, majority of the boys (50\%) and girls (42.2\%) were in normal condition.

$>$ In the age group of $18-25$ years, the majority of the males $(50 \%)$ and females $(60 \%)$ were in normal condition.

$>$ In the age group of $25-40$ years, the majority of males (50\%) were underweight and females $(55.6 \%)$ were in normal condition.

$>$ In the age group of 40-60 years, the majority of males $(77.7 \%)$ were in normal condition and females $(45.5 \%)$ were in normal condition.

\section{CONCLUSION}

SHG Programme clearly plays a central role in the lives of the poor. The SHGs in villages seem to be very successful in reaching poor clients Importantly, there is evidence of increased household income. This is a very significant indicator of impact. Standard of living for the program participants have increased and also increased the consumption of the nutritious food for family members is much more in the SHGs respondents.

SHGs loans are one of the main ways respondents overcome food insecurity with sickness, disease, emergencies and crises, where SHG participants seem to transfer the loan source from friends and moneylenders to SHG loans to meet these expenses. At the individual level, there is evidence that the SHGs attracts already relatively empowered people and that empowerment occurs among some respondents through SHG participation. The process of empowerment manifests itself in increased self-esteem. SHGs participation is also associated with changes in decision-making at the family level.

\section{Suggestions for further research:}

1. A similar study may be undertaken to compare the lifestyles of SHG beneficiaries before joining and after joining in Self Help Groups.

2. A study may be undertaken to evaluate the performance appraisal of self help groups in rural areas.

3. Similar study may be undertaken women's empowerment through NGO interventions.

4. A similar study may be undertaken covering large number of samples.

\section{REFERENCE}

[1] Angel anila, 2012, "A study on socio-economic condition of self help group members in Tirunelveli district, Tamil Nadu" , Zenith International Journal of Business Economics \& Management Research, Vol.2 Issue 2, February 2012, ISSN 22498826.

[2] AnsumanSahoo, 2013, "Self-Help Group \& woman empowerment: a study on some selected SHGs", International Journal of Business and Management Invention (ISSN), Volume 2 Issue 9\| September. 2013\| PP.54-61.

[3] Emmanuel Janagan, 2010-2011, "Empowerment of women through self help groups in India", Cauvery Research Journal (ISSN), Volume 4, Issue 1 \& 2, Jul. 2010 - Jan. 2011, PP 95-102.

[4] Jyothi Guntaka,2014, "Self-Help Groups - a tool to weaker sections women empowerment", Journal of Exclusive Management Science - November 2014 -Vol 3, Issue 11 - ISSN 2277 - 5684.

[5] Kondal Kappa, 2014, "Women Empowerment through self help groups in Andhra Pradesh, India", International Research Journal of Social Sciences-- ISSN 2319-3565 Vol. 3(1), 13-16, January (2014).

[6] Longkumer\&Jha, 2014, "Women's Empowerment through SHGs - characteristics \& levels", International Journal of Social Relevance \& Concern, ISSN No. 2347 - 9698, Vol. 2, Issue 2,

[7] PP $1-5$.

[8] Manonmani and Prabhakaran, 2010, "Women Empowerment through shg,s in Kovilangulam Panchayat, Usilampatti Taluk, madurai District -a case study", Asian Journal Of Management Research, ISSN 2229 - 3795, PP 226 -236.

[9] Mofidul Islam Jayanta Krishna Sarmah, 2014, "Impact of self help groups in empowering women: a study of rural assam", Social Change and Development Vol. XI No.2, 2014, PP 90 - 98.

[10] Maria Paulina Aguinaga Lezcano,2013, "Do self-help groups work on achieving economic goals? New evidence from a field experiment in Medellin, Colombia”,University of San Francisco USF Scholarship Repository, PP 1-48. 
[11] Nirupama Mishra, 2015, "Women Empowerment through self help groups in odisha: analysis of political networks and their space for maneuverability", Novelty Journals ISSN 2394-9694, International Journal of Novel Research in Humanity and Social Sciences, Vol. 2, Issue 4, pp: 16-23.

[12] Poornima, 2013, "Women Entrepreneurship \& empowerment through Self-Help Group in Tumkur District", International Journal of Current Engineering and Technology, ISSN $2277-4106$.

[13] Prakash, 2013, "Self-Help Groups and women empowerment with special reference to Jimmandiyur village of Pochampalli Taluk", International Journal of Advanced Research in Management and Social Sciences ISSN: 2278-6236, Vol. 2 | No. 3 | March 2013, PP 85 - 89.

[14] PreetiSharma and Shashi Kanta Varma, 2008, "Women Empowerment through entrepreneurial activities of self help groups", Indian Res. J. Ext. Edu. 8 (1), January 2008, PP 46-51.

[15] Rajani and Vijay Lakshmy, 2014, "Involvement of SHGs for women empowerment in Kerala - a theoretical approach", International Review of Research in Emerging Markets and the Global Economy (IRREM), (ISSN: 2311-3200) 2014 Vol: 1 Issue 2 PP 66-80.

[16] Ranjula Bali Swain and Fan Yang Wallentin, 2007, "Does microfinance empower women? Evidence from self help groups in india", ISSN 1653-6975, Working paper 2007:24, August 2007, PP 14-21.

[17] SanchitaGaraiet. al, 2012, "Empowerment of women through self help group approach: empirical evidence from West Bengal, India”, African Journal of Agricultural Research Vol. 7(48), pp.6395-6400, 20 December 2014.

[18] Sundaram, 2012, "Impact of elf-Help Group in socio-economic development of India", IOSR Journal Of Humanities And Social Science (JHSS) ISSN: 2279-0837, ISBN: 2279-0845. Volume 5, Issue 1 (Nov. Dec. 2012), PP 20-27.

[19] Tazyn Rahman, 2013, "Empowering rural women through Self-Help Groups and corporate partnership", Abhinav ----International Monthly Refereed Journal of Research In Management \& Technology, ISSN 2320- 0073, Volume II, May’13.

[20] Tekale et. al., 2014, "Empowerment of rural women through Self-Help Group", International J. of Exten. Edu. Vol. 10: 60-64, 2014, ISSN : 2319-7188.

[21] Vikranth Sharma, Preeti Sharma, 2014, "Impact of Self-Help Groups on women empowerment", International Journal of Social Science and Humanities Research, ISSN 2348-3164, Vol. 2, Issue 3, PP:193-198.

[22] Yoginder Singh, 2013, "Effect of self-Help Group in economic empowerment of rural women in Himachal Pradesh", Vol.1, No.3, 54-61, July-September, ISSN No. : 2321-4155. 